\title{
Designing Environmentally Friendly House Based on Buginese Local Wisdom During Covid 19 Pandemic
}

\author{
Muhammad Ardi ${ }^{1}$, Faizal Amir ${ }^{2}$, Bakhrani Abdul Rauf ${ }^{1}$, Hamzah Nur ${ }^{2}$, Alimuddin Sa'ban Miru ${ }^{3}$, \\ Yasdin $^{2}$, Mthen Lullulangi ${ }^{1, *}$ \\ ${ }^{1}$ Department of Civil Engineering and Planning Education, Faculty of Engineering Universities Negeri, Makassar, Indonesia \\ ${ }^{2}$ Department of Automotive Engineering Education, Faculty of Engineering Universities Negeri, Makassar, Indonesia \\ ${ }^{3}$ Department of Electrical Engineering Education, Faculty of Engineering Universities Negeri, Makassar, Indonesia
}

\section{Email address:}

m.ardi@unm.ac.id (M. Ardi), faizalamir64@unm.ac.id (F. Amir), bakhrani@unm.ac.id (B. A. Rau), Hamzah.nur@unm.ac.id (H. Nur), alimuddin.smiru@unm.ac.id (A. S. Miru), yasdin@unm.ac.id (Yasdi), mithen@unm.ac.id (M. Lullulangi)

${ }^{*}$ Corresponding author

\section{To cite this article:}

Muhammad Ardi, Faizal Amir, Bakhrani Abdul Rauf, Hamzah Nur, Alimuddin Sa’ban Miru, Yasdin, Mthen Lullulangi. Designing Environmentally Friendly House Based on Buginese Local Wisdom During Covid 19 Pandemic. International Journal of Architecture, Arts and Applications. Vol. 6, No. 4, 2020, pp. 71-74. doi: 10.11648/j.ijaaa.20200604.11

Received: November 9, 2020; Accepted: November 23, 2020; Published: December 4, 2020

\begin{abstract}
The purpose of this study is to explore: (1) the development of minimalist type 36, 42, and 45 two-story house plans that are safe against Covid-19, based on local wisdom of the Bugis tribe, and are environmentally sound, (2) the stages of implementing the housing design, and (3) challenges and contributing factors influencing the implementation of design development. The results of the study are as follows: (1) Development of minimalist type 36, 42, and 45 two-story house plan designs that are safe against COVID-19 posessed the following characteristics: The living room is on the first floor of the front end of the house, the family room is on the second floor, the master bedroom resides on the first or second floor not above the kitchen, children's bedrooms on the first and second floor and are not positioned above the kitchen, the dining room is on the first floor, the kitchen is on the first floor at the back and its position is facing the front, and the main door at the front house building, positioned in the middle, facing forward. (2) The stage of implementing the plan design development is to socialize and cooperate with relevant parties. (3) challenges and contributing factors of design development were due to people who have low income, have high motivation and attitudes to have a minimalist type of residence. Whereas the challenges were people who have a high income, have low motivation and attitudes to have a minimalist type of house.
\end{abstract}

Keywords: Residential Design, Minimalism, Local Wisdom of the Bugis Tribe, Covid-19

\section{Introduction}

Population growth has an impact on providing healthy and safe housing against COVID-19. Indonesian Law No. 32, the year 2009 stated that, in house planning, one should take advantage of the environment to remain sustainable [1]. Trainer (2011) further added that housings should use natural resources as needed [2]. Ardi (2017) states that housing should have a beautiful design, safe construction, and sociocultural values. Local culture or wisdom cannot be separated from the design of a home that is safe against Covid-19 [3]. Marfai (2012) states that local wisdom is another form of environmental ethics, namely a set of knowledge acquired through the learning process of a group of people [4].

Housing development by professional developers, or those built by the Bugis people themselves, development does not seem to pay attention to the local wisdom of the Bugis tribe, a sustainable environment, and various kinds of diseases that can threaten the lives of the inhabitants of the house including COVID-19 (July survey, 2018). The development of floor plans, views, and supporting facilities for a two-story minimalist type of residence that is safe against various diseases, including COVID-19, is based on local wisdom of the Bugis tribe and is not yet available in residential planning and developer consultants (January Survey, 2019).

On the basis of the previous discussion, the objectives of 
this study are to investigate: (1) the development of minimalist type 36,42 , and 45 two-story house plans that are safe against COVID-19, based on local wisdom of the Bugis, and environmentally sound, (2) stages of design implementations, and (3) challenges and contributing factors for design implementation.

The theory underlying this study is described as follows. A house is a building that functions as a place to live or shelter and a means of fostering a family (Law No. 4 of 1992) [5]. Ardi (2018) states that a house is a place where people live carry out the socialization process, have social interactions, and introduce culture [6]. Ardi (2018) states that a residence is part of a settlement, which is an environment where humans live in order to carry on life, equipped with social, economic, cultural, and service infrastructure which constitute a subsystem of the city as a whole [6].

The residence has an entrance in the form of a door, has a floor, bedroom, bathroom, toilet, dining room, kitchen, family room, living room. Residential houses have a variety of models. Current houses also have standard sizes, such as house type 36 , house type 45 , house type 54 (Wikipedia, 2019).[7]. Nurhasan (2010) states that the house is the main container for increasing the potential of human resources for all residents, which plays a strategic role in improving the morality of the people [8].

Armstrong (2009) and Edwin (2016) states that design is a personal activity to regulate everything before acting that grows from an individual's creative impulses [9, 10]. Nurhasan (2010) [8] states that the development of residential designs is mostly influenced by social, economic, and physical factors [8]..

Hamzah (2013) states that local wisdom is a source of knowledge that is dynamically organized, developed and transmitted by certain populations integrated with their understanding of the surrounding nature and culture [11]. Adyana (2012) [12] states that local wisdom is a local advantage that rests on the values, norms, ethics, knowledge, technology, and behavior of a community group and is traditionally used to overcome life and life problems [12]. Ardi (2018) states that local wisdom is a cultural product of the past that should be used as a continuation of life [6].

Ahira (2011) states that the environment is everything that is around us in the form of living things, be they humans, animals or plants [13]. Ardi (2018) [6] states that the environment is a living system in which there is human interference with the ecosystem structure [6]. Bruntland (1987) stated that sustainable development is development to meet the needs of the present generation without reducing the rights of future generations to meet their needs [14].

\section{Methodology}

This study is classified as a survey research conducted in Bone, Soppeng, and Wajo Regencies. The research sample consisted of 300 people or 15 groups which were selected by purposive sampling method. The data was collected by conducting FGD. In addition, the study also provide a questionnaire to each samples. The analysis used is descriptive qualitative analysis followed by the design process.

\section{Findings and Discussion}

\subsection{Development of Minimalist Type 36, 42, and 45}

The results of the analysis concerning the development of the living room location for minimalist type 36, 42, and 45 two-story houses that are safe against COVID-19, based on local wisdom of the Bugis tribe, and are environmentally sound show that, as many as 152 respondents $(50.67 \%)$ who stated it should be on the first floor to the front right of a housing. A total of 142 respondents (47.33\%) stated that on the first floor to the left front side. As many as 6 respondents $(2 \%)$ stated that the front on left or right side of the first floor. Therefore, the data emphasizes on the development of a twostory minimalist type 36,42 , and 45 living room layout to be at the front of the first floor house building. The living room with the size of $3 \mathrm{~m} \times 3 \mathrm{~m}$, must be cleaned every day, not stuffy, and have adequate air ventilation.

\subsubsection{Family Room Layout Development}

The results of the analysis of the development of the family room location for minimalist type 36, 42, and 45 twostory houses that are safe against COVID-19, based on local wisdom of the Bugis tribe, and have an environmental insight show that, as many as 297 respondents (99\%) stated that it should be on the second floor. A total of 3 respondents (1\%) stated the first floor. On the basis of the previous description, it can be concluded that the development of the family room is on the second floor at the front or back of the house building. The size of this family room should at least be $3 \mathrm{~m} \times 3 \mathrm{~m}$. The family room must be cleaned every day, not stuffy, and have adequate air ventilation.

\subsubsection{Development of the Master Bedroom Location}

The results of the analysis of the development of the father's and mother's bedrooms for minimalist type 36, 42, and 45 two-story houses that are safe against COVID-19, based on local wisdom of the Bugis tribe, and environmental insight show that 144 respondents $(48 \%)$ stated the optimal design should be on the first floor of the front of a house. A total of 156 respondents $(52 \%)$ stated that the second floor front of the house. Based on the previous description, it can be concluded that, the development of the master bedroom is located on the first or second floor of the front of the house, either left or right and does not face the main door of the house. When placed on the second floor, it is not positioned above the kitchen. Minimum room size $3 \mathrm{mx} 3 \mathrm{~m}$. The master bedroom must be cleaned every day, not stuffy, and have adequate air ventilation.

\subsubsection{Development of Children's Bedroom Layout}

The results of the analysis of children's bedrooms for minimalist type 36,42 , and 45 two-story houses that are safe against COVID-19, based on the local wisdom of the Bugis 
tribe, and are environmentally sound show that 162 respondents $(54 \%)$ stated the second floor and not above the kitchen to be ideal. A total of 138 respondents $(46 \%)$ stated the front second floor of the house. Based on the previous description, it can be concluded that the development of the layout of children's bedrooms, were on the first floor at the front and the second floor away from the kitchen. The position of the children's bedroom should be easy to control, not facing the main door, and not located on corners of the house. The size of the dining room is at least $3 \mathrm{mx} 3 \mathrm{~m}$, cleaned every day, not stuffy, and has adequate air ventilation.

\subsubsection{Development of the Dining Room Layout}

The results of the analysis of the dining room development location for minimalist type 36,42 , and 45 two-storey houses show that all respondents (100\%) stated that they are ideal on the first floor at the back end of the house. Based on the results of the previous analysis for the two-story minimalist type house (type 36), the development of the location of the dining room should be adjacent to or facing the kitchen. On the basis of the previous description, it can be understood that the location of the development of the dining room is on the first floor, behind the living room, facing the kitchen, in the center of the house. The size of the dining room is at least $3 \mathrm{~m} \times 3 \mathrm{~m}$, cleaned every day, not stuffy, and has adequate air ventilation.

\subsubsection{Development of Kitchen Location and Position}

The results of the analysis from the 300 samples concerning the ideal location of the kitchen and its position for minimalist type 36, 42, and 45 two-storey houses that are safe against COVID-19, based on local wisdom of the Bugis and environmentally sound, show that all respondents (100\%) stated that the kitchen is positioned at the back of the house, facing forward and sideways. In addition, this position is considered good luck and easy to see if there are people who want to visit. Minimum kitchen size is $2 \mathrm{mx} 2 \mathrm{~m}$, cleaned every day, not stuffy, and has adequate air ventilation.

\subsubsection{Development of Main Door (Home Entrance)}

The results of the analysis with regards to the development of main door location for minimalist type 36, 42, and 45 twostory houses that are safe against COVID-19, based on local wisdom of the Bugis tribe and being environmentally sound show that all respondents $(100 \%)$ stated their position should be in the center front of the house. The main door faces forward, which is in the direction of the house. The main door should not face sideways and face into the bedroom. The main door facing sideways often brings havoc. It is believed that the main door that hits the bedroom has a bad impact on the residents of the house.

\subsection{Development Stages of Minimalist Type 36, 42, and 45}

\subsubsection{Socializing}

The results of the analysis to the first steps that must be taken to implement the development of a minimalist type of two-story house plan design (types 36, 42, and 45) that are safe against COVID-19, are based on local wisdom of the
Bugis tribe, and are environmentally sound, revealed as many as 285 respondents $(95 \%)$ supporting in the socialization of design development to planning consultants, housing developers, and user communities. As many as 15 respondents (5\%) stated that they should just apply it. Based on the previous description, it can be concluded that, the first step taken for the application of design development is to conduct socialization to planning consultants, housing developers, and similar design communities.

\subsubsection{Cooperation}

The results of the analysis for the third step that must be taken to implement the development of a minimalist type of two-story house plan design (types 36, 42, and 45) that are safe against COVID-19, based on local wisdom of the Bugis tribe, and are environmentally sound, show as many as 279 respondents (93\%) stated that they cooperate with planning consultants, housing developers and user communities. As many as 21 respondents (7\%) stated that it was enough just to give an example. Based on the previous description, it can be concluded that, the third step for implementing the design is to cooperate with planning consultants, housing developers, and the similar design community.

\subsection{Challenges and Contributing Factors for the Housing Development}

\subsubsection{Low Income Communities}

The results of the analysis for low-income people are a supporting factor for the implementation of the housing design of a minimalist type of two-story residential house plan (types 36, 42, and 45) with a total of 294 respondents (98\%) who strongly agree. A total of 6 respondents $(2 \%)$ expressed doubts. Based on the previous description, it can be concluded that low-income people are a supporting factor for design implementation. On the other hand, the complication factor delas with high-income society.

\subsubsection{Motivation and Attitudes of the Communities}

The results of the analysis of the high motivation and attitudes of the community to have a minimalist type of residence that is safe against COVID-19, based on local wisdom of the Bugis tribe, and is environmentally sound are supporting factors for the development of a minimalist type of two-story house plan design (type 36, 42, and 45) indicate that, as many as 285 respondents $(95 \%)$ who strongly agreed, 15 respondents $(5 \%)$ expressed doubt. Based on the previous description, it can be concluded that the motivation and high attitudes of the community to have a minimalist type of residence is a supporting factor for the implementation of the design. Conversely, the low motivation and attitude of the community to own a minimalist type of house is a complication.

\section{Conclusion}

There were several conclusons that can be found for the he development of minimalist type 36,42 , and 45 two-story 
house plan designs that are safe against COVID-19, based on the local wisdom of the Bugis, and are environmentally sound. First is the ideal location based on local wisdom of the bugis: (a) the living room is on the first floor of the front of the house, ( b) the family room is on the second floor, (c) the master bedroom is on the first floor or the second floor of the front of the house, if it is on the second floor, it is not positioned above the kitchen (d) the children's bedroom can either be on the first or second floor, if on the second floor, it is not positioned above the kitchen, (e) the dining room is on the first floor, (f) the kitchen is on the first floor at the back and its position is facing the front, $(\mathrm{g})$ the main door is on the first floor. front of the house, positioned in the middle, facing the front.

The stages of implementing the development of minimalist type 36, 42 and 45 two-story house plan designs that are safe against COVID-19, based on the local wisdom of the Bugis and environmentally sound were: (a) socializing and (b) working with planning consultants, housing developers, and user communities.

Supporting factors for the development of a minimalist type of two-story house plan design that is safe against COVID-19, based on local wisdom of the Bugis and environmentally friendly were: (a) people with low income and (b) people who have high motivation and attitudes to have a minimalist type of residence. Complication factors were: (a) people with high income and (b) people who have low motivation and attitudes to own a minimalist type of house.

\section{Acknowledgements}

Acknowledgments are conveyed to: 1) Ministry of Research and Technology / National Agency for Research and Technology and the Director General of Higher Education for funding this research as a form of coaching lecturers in Higher Education, 2) Rector of the State University of Makassar for his permission, guidance, and motivation so that this research was carried out well. 3) Chairman of the Institute for Research and Community Service (LP2M) Makassar State University for his support and direction in conducting this research well. 4) Soppeng and Sidrap District Governments for their support and granting of permits to conduct research. 5) Farmers as research respondents for their participation and cooperation. 6) All members of the research team for their good cooperation, and 7) All parties who have participated in this research who were not mentioned one by one.

Hopefully what all parties have done in completing this research can provide the greatest benefit for Makassar State University, Society, Nation and State.

\section{References}

[1] Undang-Undang R. I. Nomor 32 Tahun 2009 Tentang Perlindungan dan Pengelolaan Lingkungan Hidup.

[2] Trainer, Ted. (2011). The Radical Implication of a Zero Growth Economy 1 (http://rwer.wordpress.com/2011/09/06/rwer-issue-57-Trainer/, diakses 15 September 2018).

[3] Muhammad Ardi, Bakhrani A. Rauf, dan Mithen. (2017). Desain Rumah Tinggal Berbasis Kearifan lokal Suku Bugis Yang Berwawasan Lingkungan. Makassar: Badan Penerbit UNM.

[4] Marfai. (2012). Pengantar Etika Lingkungan dan Kearifan Lokal. Yogyakarta: UGM Press.

[5] Undang-Undang R. I. No. 4 Tahun 1992 Tentang Perumahan dan Permukiman.

[6] Muhammad Ardi, Mithen, Bakhrani A. Rauf, dan Faizal Amir. (2018). Desain Tampak Rumah Tinggal Berbasis Kearifan Lokal Suku Bugis Yang Berwawasan Lingkungan. Makassar: Badan Penerbit UNM.

[7] Wikipedia Online. 2019 https://id.wikipedia.org/wiki/Special:Search?search= rumah+ tinggal\&go=Go\&ns0=1. Diakses 19 April 2019.

[8] Nurhasan, Indrawati dan Riza Zahrul Islam. (2010). "Pendekatan DesainRumah Sederhana Sehat (rs sehat) dan LingkungannyaBerdasarkan Arsitektur Islam." Laporan Penelitian. Solo: Universitas Muhamadiyah Solo.

[9] Armstrong, Helen. (2009) Graphic Design Theory Reading from The Field. (Terjemahan: Indrajaya, Erastus Hans). Yogyakarta: Penerbit Andi.

[10] Edwin, dkk. (2016). "Perancangan Rumah Tinggal." https://www.academia.edu/ 28635798/perancangan_rumah_tinggal). Diakses 13 Mei 2019.

[11] Hamzah, M. (2013). Pendidikan Lingkungan, Sekelumit Wawasan Pengantar. Bandung: Refika Aditama.

[12] Adyana, P. (2012). Wacana Tembang Macapat sebagai Pengungkap Sistem Kognisi dan Kearifan Lokal Etnik Jawa. Publikasiilmiah.ums.ac.id. Volume 2. No. 22. Desember 2012.

[13] Ahira, Anne. (2011). Kesehatan Lingkungan Perumahan. (ww.anneahira.com/ kesehatan-lingkungan-permukiman. htm, diakses 22 April 2019).

[14] Bruntland, G. H. (1987), "World Commission on Environment and Development", dalam "Our Common Future”, Oxford: Oxford University Press. 